Ann. Rept. Kansai PI. Prot. (61): 1-8 (2019)

\title{
スナップエンドウで発生したナモグリバエ寄生蜂の 種構成と地域間差異
}

\author{
太田 泉・浦入千宗・安部順一朗* - 水谷信夫** ・ 柿元一樹*** 一大野和朗**** \\ Izumi Ohta, Chihiro Urairi, Jun-ichiro Abe*, Nobuo Mizutani**, Kazuki Kakimoto*** \\ and Kazuro Ohno****: Species composition of hymenopterous parasitoids \\ attacking a garden pea leaf-miner fly, Chromatomyia horticola (Diptera: Agromyzidae) \\ on garden pea plants and its regional differences in Japan
}

\begin{abstract}
The species composition of hymenopterous parasitoids attacking a garden pea leaf-miner fly, Chromatomyia horticola on garden pea plants was investigated at three locations in Japan. In Tsu, Mie Prefecture, Halticoptera circulus, Diglyphus isaea, Dacnusa nipponica, and Diglyphus minoeus predominantly emerged from C. horticola mines. D. nipponica was the dominant species in Fukuyama, Hiroshima Prefecture. Meanwhile, H. circulus, D. nipponica, Opius spp., and D. isaea were collected in large numbers in Koshi, Kumamoto Prefecture. These results revealed marked regional differences in parasitoid species composition. In addition, we compared these results with the results of corresponding surveys in other places.
\end{abstract}

Key words: Chromatomyia horticola, garden pea, parasitoids, dominant species

\section{緒言}

ナモグリバエ Chromatomyia horticola（Goureau）は, マメ科, アブラナ科, キク科作物の害虫として知られ ており（小西, 2007 ; 新藤ら, 2008), 特に, 春どりの エンドウで激しい被害を発生させることが多い（藤原 ら, 2007 ; 東浦ら，2011)。北海道では, サヤエンドウ でナモグリバエが恒常的に発生し，収量の低下や莒への 幼虫の食入によって収穫物が規格外となる被害が多発 している（水越・戸川, 1999)。また, レタス, ダイコ ン, ハクサイ, インゲンなどでもナモグリバエの多発生 が問題となっている（西東，2005）。一方，ナモグリバ エには，20種以上の寄生蜂が寄生することが知られてお り (Takada and Kamijo, 1979 ; 小西, 2007 ; Saito et al., 2008), 野外では, 寄生蜂はナモグリバエの密度抑制因 子として大きく影響していると考えられている（西東, 2005 ; 福原・高木, 2007 ; 柿元・太田, 2017)。
近年, 露地栽培の野菜類などでは, 持続的で省力的な 害虫防除技術として, 固場やその周辺に生息する土着天 敵を活用した防除体系の構築が求められている。そこで, 本研究では, 春どりのスナップエンドウにおけるナモグ リバエの抑制技術を開発することを目的として，日本国 内の複数箇所でスナップエンドウを栽培し, そこで発生 したナモグリバエ寄生蜂の発生消長や種構成を明らかに した。また, ナモグリバエ寄生蜂の種構成を地域間で比 較することで, ナモグリバエの発生抑制に重要な優占種 を明らかにした。

本研究におけるナモグリバエ寄生蜂の種同定は, 小西 和彦博士（愛媛大学農学部）にご教示いただいた。この 場を借りて厚く御礼申し上げる。また, 本研究は, 農林 水産業・食品産業科学技術研究推進事業「登録農薬の少 ない地域特産作物（マイナー作物）における天敵利用技

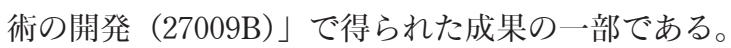

農研機構野菜花き研究部門・*農研機構西日本農業研究センター・**農研機構九州沖縄農業研究センタ一・***鹿児島県農業開発 総合センター・****宮崎大学農学部 Institute of Vegetable and Floriculture Science, NARO, *Western Region Agricultural Research Center, NARO, **Kyushu Okinawa Agricultural Research Center, NARO, ***Kagoshima Prefectural Institute of Agricultural Development, ****University of Miyazaki 2018年11月 1 日受理

責任著者：太田 泉・ohtaiz@affrc.go.jp 
材料および方法

1. 三重県津市におけるハモグリバエ類と寄生蜂の発生 状況（2016年 1 月～4 月）

(1) 耕種概要

調査は，農研機構野菜花き研究部門安濃野菜研究拠点 （三重県津市）内の露地圃場で行った。幅 $70 \mathrm{~cm}$, 長さ $9 \mathrm{~m}$ の喃を南北方向に 3 本作り（欯と欯の間の通路幅は $80 \mathrm{~cm}$ ), 2015年10月14日にスナップエンドウ（品種：二 ムラサラダスナップ，みかど協和 $(($ 株 $)))$ を弶上に 20 $\mathrm{cm}$ 間隔で定植した。なお，スナップエンドウは，定植 後に苗立枯病が発病する可能性があったため，同年10月 1 日に72穴のセルトレーに播種してガラス温室内で育苗 したものを橉場に定植した。その後の栽培は慣行にした がった。殺虫剤等の農薬散布は行わなかった。

\section{（2）調査方法}

調査は，2016年 1 月 13 日， 1 月 26 日，2月 8 日， 2 月 22 日，3 月 8 日，3 月 22 日，4 月 5 日および 4 月 19 日に 行った。スナップエンドウを植えた各喃を $1.5 \mathrm{~m}$ ごとに 区切り，調査日毎に各区から任意の 2 株を選んだ（合計 36株)。地面からそれぞれ高さ $0 \sim 10 \mathrm{~cm} ， 30 \sim 50 \mathrm{~cm}$ お よび60～ $80 \mathrm{~cm}$ にある複葉を 1 枚ずつ採集して（以下， 下位葉，中位葉，上位葉と称する)，実験室に持ち帰った。 採集する複葉の高さは，スナップエンドウの生長に合わ せて適宜上方に移動させた。各複葉に付いているハモグ リバエ類のマイン（幼虫および囲蛹）の個体数を記録し た後，温度 $25^{\circ} \mathrm{C}$, 日長 $14 \mathrm{~L}-10 \mathrm{D}$ に維持した恒温室内で 3 週間保存し，マインから羽化したハモグリバエ類や寄 生蜂の種類と個体数を記録した。羽化しなかったマイン はマイン内部を切開して，ハモグリバ工類や寄生蜂が死 亡しているものを死ごもりとした。寄生蜂の種同定では, 小西（2010）の検索表を参考にするとともに，寄生蜂の 標本の一部は小西和彦博士に送付して, 誤同定がないこ とを確認した（以下の種同定作業も同じ）。

2. 三重県津市におけるハモグリバエ類と寄生蜂の発生 状況（2016年12月～2017年 5 月）

\section{(1) 耕種概要}

調査場所と栽培したスナップエンドウの品種は前年と 同じある。幅 $70 \mathrm{~cm}$ ，長さ $8 \mathrm{~m}$ の献を東西方向に 3 本作 り（嘼と喃の間の通路幅は $80 \mathrm{~cm}$ ), これを 2 箇所設置 した。スナップエンドウの定植は，2016年 9 月16日と 11 月 1 日の 2 回に分けて行った。 1 回目は，9月16日に各 畧の中央から約 $10 \mathrm{~cm}$ 北側の位置にスナップエンドウの 苗を $20 \mathrm{~cm}$ 間隔で一列に植えた。2 回目は，11月 1 日に 同弶の中央から約 $10 \mathrm{~cm}$ 南側の位置に苗を一列に定植し た。その後の栽培は慣行にしたがった。殺虫剤等の農薬
散布は行わなかった。

(2) 調査方法

2017年 1 月26日の朝に強い降霜があり，その後，9月 に定植した株はほぼ枯死した。そのため，9月定植の株 を対象とした調査は，2016年11月25日，12月26日，2017 年 1 月10日および1月26日に行った。2箇所の戋場から マインが付いているスナップエンドウの小葉を任意に採 集し（枚数は不定），その後は前年と同じ方法で八モグ リバエ類と寄生蜂を羽化させて, その種類と個体数を記 録した。また，11月に定植した株については，4 月28日， 5 月 8 日，5月18日にマインが付いている小葉を採集し (枚数は不定), マインから羽化したハモグリバエ類や寄 生蜂の種類と個体数を記録した。

3. 広島県福山市におけるハモグリバエ類と寄生蜂の発 生状況（2016年12月～2017年 3 月）

\section{(1) 耕種概要}

調査は, 農研機構西日本農業研究センター（広島県 福山市）内の露地圃場で行った。幅 $80 \mathrm{~cm}$, 長さ $10 \mathrm{~m}$ の畧を東西方向に 2 本作り（㽞と喃の間の通路幅は 120 $\mathrm{cm})$ ，これを 3 箇所設置した。2016年10月16日にスナッ プエンドウ（品種：ニムラサラダスナップ）を楠上に $15 \mathrm{~cm}$ 間隔で播種した。その後の栽培は慣行にしたがっ た。殺虫剂等の農薬散布は行わなかった。

(2) 調査方法

2016年12月 20 日，2017年 1 月 27 日， 2 月 22 日， 3 月 8 日および 3 月28日に，3 箇所の國場からハモグリバエ類 のマインが付いているエンドウの小葉を任意に採集して (枚数は不定), 実験室に持ち帰った。エンドウの小葉は, 温度 $23^{\circ} \mathrm{C}$, 日長 $16 \mathrm{~L}-8 \mathrm{D}$ に維持した恒温室内で保存し, マインから羽化したハモグリバエ類や寄生蜂の種類と個 体数を記録した。

4. 熊本県合志市におけるハモグリバエ類と寄生蜂の発 生状況（2016年11月～2017年4月）

\section{(1) 耕種概要}

調査は, 農研機構九州沖縄農業研究センター（熊本県 合志市）内の露地圃場で行った。幅 $60 \mathrm{~cm}$, 長さ $10 \mathrm{~m}$ の畧を南北方向に 5 本作り（喃と喃の間の通路幅は 80 $\mathrm{cm})$ ，これを 3 箇所設置した。2016年 9 月27日にスナッ プエンドウ（品種：ニムラサラダスナップ）を喃上に $15 \mathrm{~cm}$ 間隔で播種した。また, 上記の各圃場から約 $8 \mathrm{~m}$ 離れた場所に 3 本の暔を作り, 同様の方法で 12 月 2 日に スナップエンドウを播種した。その後の栽培は慣行にし たがった。殺虫剂等の農薬散布は行わなかった。

\section{（2）調査方法}

2017年 1 月24日と 25 日の朝に強い降霜があり,その後, 
9 月播種の株はほぼ枯死した。そのため，9月播種の株 を対象とした調查は，2016年11月17日，11月22日，11月 28日，12月 6 日，12月12日，12月19日，12月28日，2017 年 1 月17日，1月26日に行った。また，12月播種の株を 対象とした調查は，3 月 22 日，4 月13日および 4 月28日 に行った。3 䇢所の戋場から調査日毎に任意に18株ずつ を選び，各株 1 ないし 2 枚の複葉を採集して，実験室に 持ち帰った(小葉で20～60枚/筒所)。エンドウの小葉は, 温度 $25^{\circ} \mathrm{C}$, 日長 $16 \mathrm{~L}-8 \mathrm{D}$ に維持した恒温室内で最長 4 週 間保存し，マインから羽化した八モグリバエ類や寄生蜂 の種類と個体数を記録した。

\section{結果}

1. 三重県津市におけるハモグリバエ類と寄生蜂の発生 状況（2016年1月～4月）

スナップエンドウ上では，調査を開始した2016年 1 月 13日からハモグリバエ類によるマインが確認された（第 1 図)。3 月 22 日までは, 調査 1 回当たり合計 $31 \sim 95$ 個 のマインが観察され，そのほとんどは下位葉と中位葉に 存在していた。その後, マイン数は増加し，4月 5 日は 545個，最終調査日の 4 月19日には1622個が認められた。 また，4月19日に観察されたマインの76.8\%は，上位葉 に存在していた。

採集したマインからは，調查期間全体を通して，ナ モグリバエと寄生蜂が羽化した（第 2 図）。八モグリバ エ類はナモグリバエ 1 種のみだった。マインから羽化 した寄生蜂の割合（寄生蜂の個体数/マイン数）は, 1 月13日は77.4\%と高かったが，2月22日には26.7\%ま で減少し，その後再び増加して 4 月19日には $41.6 \%$ と なった。寄生蜂は 9 種が確認された（第 1 表）。最も多 く羽化した寄生蜂はコガネコバチ科（Pteromalidae）の Halticoptera circulus（Walker）(40.2\%）であり，次いで ヒメコバチ科 (Eulophidae) の Diglyphus isaea (Walker) (34.7\%), コマユバチ科 (Braconidae) の Dacnusa nipponica Takada（17.9\%）であった。H. circulus は1月13日から 4 月19日の調査期間全体を通して羽化が認められたが, Di. isaea と Da. nipponica は 3 月 22 日以降に羽化数が増 加した。寄生蜂による寄生率（寄生蜂の羽化個体数/(八 モグリバエ類の羽化個体数+寄生蜂の羽化個体数), 以 下同様）は，1月13日の時点で $85.7 \%$ と高く，2 月22日 と 3 月 8 日には $30 \%$ 程度まで低下したが，その後再び増 加して，4月19日には76.8\%となった。

2. 三重県津市におけるハモグリバエ類と寄生蜂の発生 状況（2016年12月～2017年5月）

八モグリバエ類のマインからは，ナモグリバエと寄生

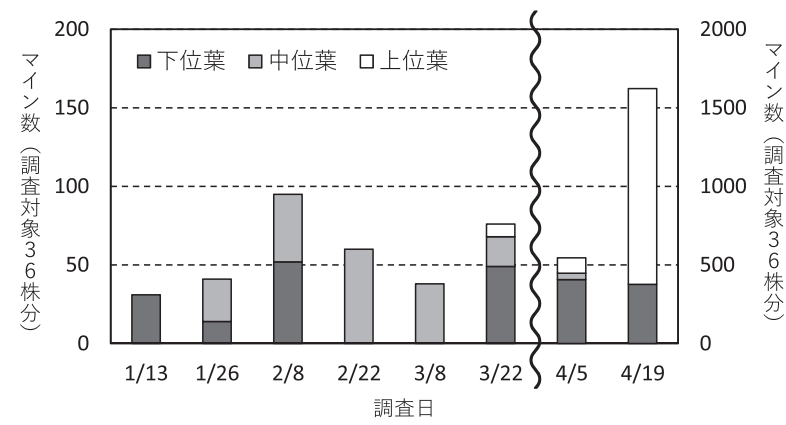

第1図 スナップエンドウにおけるハモグリバエ類のマインの 発生推移（三重県津市, 2016年 1 4 月）

1 月 13 日から 3 月 22 日までのデータは左側縦軸のス ケール，4月 5 日と 4 月 19 日は右側縦軸のスケールで 表示。

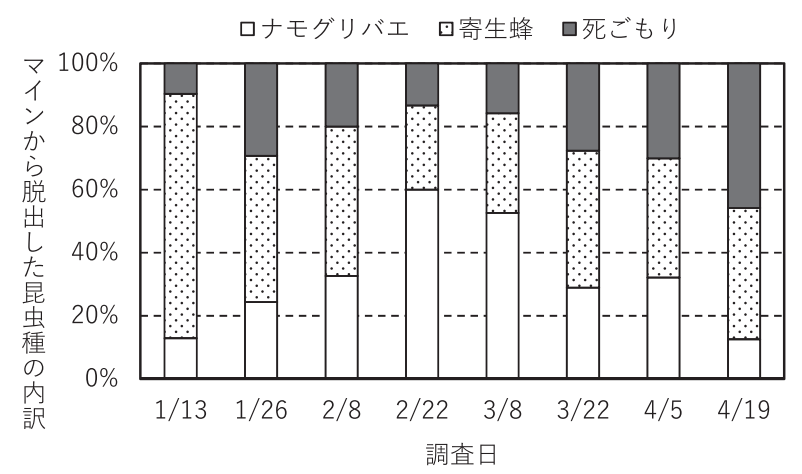

第2図スナップエンドウ上のマインから羽化した昆虫種の内 訳（三重県津市，2016年 1～4月）

蜂13種が羽化した（第 2 表）。最も多く羽化した寄生蜂 はH. circulus (43.0\%) であり,次いでDi. isaea (26.8\%), 同じヒメコバチ科 (Eulophidae) の Diglyphus minoeus (Walker) (22.2\%) であった。H. circulus と Di. minoeus は12月26日から 5 月18日までの調査期間全体を通して 羽化が認められたが, Di. isaea は 4 月28日以降に増加し た。また, Da. nipponica は 4 月28日に多く羽化した。寄 生蜂による寄生率は，12月と 1 月は $40 \%$ 前後だったが, 4 月28日は74.3\%に増加し，5月採集のマインではほぼ 100\%であった。

3. 広島県福山市における八モグリバエ類と寄生蜂の発 生状況（2016年12月～2017年3月）

八モグリバエ類のマインからは, ナモグリバエと寄 生蜂 9 種が羽化した (第 3 表)。最も多く羽化した寄生 蜂はDa. nipponica（75.9\%）であり, 次いでH. circulus (14.8\%) であった。H. circulus は12月20日から 3 月 8 日の間で羽化が認められた。一方，3 月28日には，ヒ メコバチ科 (Eulophidae) の Chrysocharis pubicornis （Zetterstedt）も多く羽化した。寄生蜂の寄生率は, 12 
第 1 表 スナップエンドウのマインから羽化したハモグリバエ類と寄生蜂の個体数と種構成（三重県津市, 2016年 1 ～4 月)

\begin{tabular}{|c|c|c|c|c|c|c|c|c|c|c|}
\hline & 1月13日 & 1月26日 & 2 月 8 日 & 2 月22日 & 3 月 8 日 & 3 月 22 日 & 4 月 5 日 & 4月19日 & 合計 & 構成比 (\%) \\
\hline \multicolumn{11}{|l|}{ 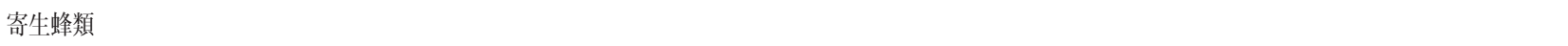 } \\
\hline \multicolumn{11}{|l|}{ コマユバチ科 (Bracinidae) } \\
\hline Dacnusa nipponica Takada, 1977 & 5 & & 5 & & & 17 & 65 & 83 & 175 & 17.9 \\
\hline Opius spp. & & & 1 & & & & 3 & 10 & 14 & 1.4 \\
\hline \multicolumn{11}{|l|}{ コガネコバチ科（Pteromalidae） } \\
\hline Halticoptera circulus (Walker, 1833) & 18 & 18 & 39 & 16 & 12 & 5 & 26 & 260 & 394 & 40.2 \\
\hline Merismus sp. & 1 & & & & & & & & 1 & 0.1 \\
\hline Sphegigaster hamugurivora Ishii, 1953 & & & & & & & 1 & 4 & 5 & 0.5 \\
\hline \multicolumn{11}{|l|}{ ヒメコバチ科（Eulophidae） } \\
\hline Diglyphus isaea (Walker, 1838) & & & & & & 8 & 43 & 289 & 340 & 34.7 \\
\hline Diglyphus minoeus (Walker, 1838) & & 1 & & & & 3 & 3 & 8 & 15 & 1.5 \\
\hline Pnigalio katonis (Ishii, 1953) & & & & & & & & 2 & 2 & 0.2 \\
\hline Neochrysocharis formosa (Westwood, 1833) & & & & & & & & 2 & 2 & 0.2 \\
\hline 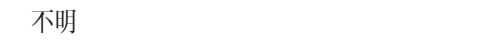 & & & & & & & 15 & 17 & 32 & 3.3 \\
\hline \multicolumn{11}{|l|}{ ハモグリバエ類 } \\
\hline Chromatomyia horticola (Goureau, 1851) & 4 & 10 & 31 & 36 & 20 & 22 & 175 & 204 & 502 & \\
\hline 寄生率 $(\%)^{a)}$ & 85.7 & 65.5 & 59.2 & 30.8 & 37.5 & 60.0 & 47.1 & 76.8 & 66.1 & \\
\hline
\end{tabular}

a) 寄生蜂類の個体数/(ハモグリバエ類の個体数 + 寄生蜂類の個体数 $) \times 100$

第 2 表 スナップエンドウのマインから羽化したハモグリバエ類と寄生蜂の個体数と種構成（三重県津市，2016年12月～2017年 1 月 および2017年 4 〜 月)

\begin{tabular}{|c|c|c|c|c|c|c|c|c|}
\hline & 12月 26 日 & 1月11日 & 1月26日 & 4 月28日 & 5 月 8 日 & 5 月18日 & 合計 & 構成比（\%） \\
\hline \multicolumn{9}{|l|}{ 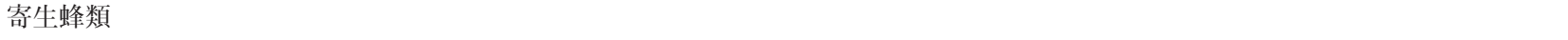 } \\
\hline Dacnusa nipponica Takada, 1977 & 1 & & 2 & 117 & 18 & 11 & 149 & 5.0 \\
\hline \multicolumn{9}{|l|}{ コガネコバチ科（Pteromalidae） } \\
\hline Halticoptera circulus（Walker, 1833） & 197 & 134 & 139 & 508 & 252 & 52 & 1282 & 43.0 \\
\hline Merismus sp. & & & 6 & & & & 6 & 0.2 \\
\hline Sphegigaster hamugurivora Ishii, 1953 & 1 & & & & 3 & 6 & 10 & 0.3 \\
\hline \multicolumn{9}{|l|}{ ヒメコバチ科（Eulophidae） } \\
\hline Chrysocharis pentheus（Walker, 1839) & 3 & 1 & 1 & 10 & 10 & 10 & 35 & 1.2 \\
\hline Chrysocharis pubicornis (Zetterstedt, 1838) & 3 & 6 & 2 & 2 & 3 & 2 & 18 & 0.6 \\
\hline Diglyphus albiscapus Erdös, 1951 & & & & & 12 & & 12 & 0.4 \\
\hline Diglyphus isaea（Walker, 1838） & & 1 & 2 & 344 & 311 & 142 & 800 & 26.8 \\
\hline Diglyphus minoeus (Walker, 1838) & 65 & 49 & 58 & 135 & 194 & 160 & 661 & 22.2 \\
\hline Hemiptarsenus varicornis（Girault, 1931） & & 1 & & & & 2 & 3 & 0.1 \\
\hline Neochrysocharis formosa (Westwood, 1833) & & & & 1 & 1 & & 2 & 0.1 \\
\hline Neochrysocharis okazakii Kamijo, 1978 & & & & 1 & & & 1 & 0.0 \\
\hline Pnigalio katonis (Ishii, 1953) & 4 & & & & 1 & & 5 & 0.2 \\
\hline \multicolumn{9}{|l|}{ ハモグリバエ類 } \\
\hline Chromatomyia horticola (Goureau, 1851) & 414 & 244 & 336 & 387 & 16 & 2 & 1399 & \\
\hline 寄生率 $(\%)^{\mathrm{a})}$ & 39.8 & 44.0 & 38.5 & 74.3 & 98.1 & 99.5 & 68.1 & \\
\hline
\end{tabular}

a) 寄生蜂類の個体数/(ハモグリバエ類の個体数 + 寄生蜂類の個体数 $) \times 100$

月から 2 月は $60 \%$ 前後だったが， 3 月には約30\%に減少 した。

\section{4. 熊本県合志市におけるハモグリバエ類と寄生蜂の発 生状況（2016年11月～2017年4月） \\ ハモグリバエ類のマインからは, 16種の寄生蜂が羽化}

した（第 4 表）。羽化した八モグリバエ類はほぼナモグ リバエであり，12月６日に採集したマインからマメハモ グリバエ Liriomyza trifolli（Burgess）が1頭だけ羽化し た。最も多く羽化した寄生蜂は H. circulus（31.1\%）で あり，次いでDa.nipponica (17.2\%)，同じコマユバチ 
太田 泉・浦入千宗・安部順一朗・水谷信夫・柿元一樹・大野和朗 : ナモグリバエ寄生蜂の種構成

第 3 表 スナップエンドウのマインから羽化したハモグリバエ類と寄生蜂の個体数と種構成 (広島県福山市, 2016年12月～2017年 3 月）

\begin{tabular}{|c|c|c|c|c|c|c|c|}
\hline & 12月20日 & 1月27日 & 2 月 22 日 & 3 月 8 日 & 3 月28日 & 合計 & 構成比（\%） \\
\hline \multicolumn{8}{|l|}{ 寄生蜂類 } \\
\hline \multicolumn{8}{|l|}{ コマユバチ科（Bracinidae） } \\
\hline Dacnusa nipponica Takada, 1977 & 50 & 201 & 145 & 80 & 33 & 509 & 75.9 \\
\hline コガネコバチ科（Pteromalidae） & & & & & 7 & & \\
\hline Halticoptera circulus (Walker, 1833) & 52 & 13 & 20 & 14 & & 99 & 14.8 \\
\hline Merismus sp. & & & 1 & & & 1 & 0.1 \\
\hline \multicolumn{8}{|l|}{ ヒメコバチ科（Eulophidae） } \\
\hline Chrysocharis pubicornis (Zetterstedt, 1838) & 2 & 10 & 5 & 1 & 22 & 40 & 6.0 \\
\hline Diglyphus isaea (Walker, 1838) & & 8 & 2 & 2 & & 12 & 1.8 \\
\hline Diglyphus minoeus（Walker, 1838) & & & 2 & & & 2 & 0.3 \\
\hline Diglyphus pusztensis (Erdös and Novicky, 1951) & & 1 & & & & 1 & 0.1 \\
\hline Neochrysocharis formosa（Westwood, 1833） & 1 & 2 & 1 & 2 & & 6 & 0.9 \\
\hline Pnigalio katonis (Ishii, 1953) & & & & & 1 & 1 & 0.1 \\
\hline \multicolumn{8}{|l|}{ ハモグリバエ類 } \\
\hline Chromatomyia horticola (Goureau, 1851) & 66 & 112 & 118 & 220 & 133 & 649 & \\
\hline 寄生率 (\%) ${ }^{\mathrm{a})}$ & 61.4 & 67.7 & 59.9 & 31.0 & 32.1 & 50.8 & \\
\hline
\end{tabular}

a) 寄生蜂類の個体数/(ハモグリバエ類の個体数 + 寄生蜂類の個体数 $) \times 100$

第 4 表 スナップエンドウのマインから羽化したハモグリバエ類と寄生蜂の個体数と種構成 (熊本県合志市, 2016年11月～2017年 4 月) 11月17日 11月22日 11月28日 12月6日 12月12日 12月19日 12月28日 1月6日 1月17日 1月26日 3月22日 4月13日 4月28日 合計 構成比 (\%)

\begin{tabular}{|c|c|c|c|c|c|c|c|c|c|c|c|c|c|c|c|}
\hline $\begin{array}{l}\text { 寄生蜂類 } \\
\text { コマユバチ科 (Bracinidae) }\end{array}$ & & & & & & & & & & & & & & & \\
\hline Dacnusa nipponica Takada, 1977 & & & & 1 & & 1 & 7 & 1 & 3 & & 11 & 37 & 223 & 284 & 17.2 \\
\hline Opius spp. & & & & & & & & & & 1 & 3 & 15 & 238 & 257 & 15.6 \\
\hline コガネコバチ科 (Pteromalidae) & & & & & & & & & & & & & & & \\
\hline Halticoptera circulus（Walker, 1833) & & & & & 1 & & 1 & 3 & 5 & 5 & 76 & 63 & 360 & 514 & 31.1 \\
\hline Sphegigaster hamugurivora Ishii, 1953 & & & & & & & & & 2 & & 18 & & 111 & 131 & 7.9 \\
\hline Trichomalopsis oryzae Kamijo \& Grissell, 1982 & & & & & & & & & & & & & 1 & 1 & 0.1 \\
\hline ヒメコバチ科（Eulophidae） & & & & & & & & & & & & & & & \\
\hline Acecodes erxias (Walker, 1848) & & & & & & & & & & & & & 3 & 3 & 0.2 \\
\hline Chrysocharis pentheus（Walker, 1839) & & & & & & & & & & & & 11 & 150 & 161 & 9.7 \\
\hline Chrysocharis pubicornis (Zetterstedt, 1838) & & & & & & & & & 1 & & & 1 & 17 & 19 & 1.2 \\
\hline Closterocerus trifasciatus（Griault, 1913) & & & & & & & & & & & & & 9 & 9 & 0.5 \\
\hline Diglyphus albiscapus Erdös, 1951 & & & & & & & & & & & & & 16 & 16 & 1.0 \\
\hline Diglyphus isaea (Walker, 1838) & & & & & & & & & & & 2 & & 184 & 186 & 11.3 \\
\hline Diglyphus minoeus (Walker, 1838) & & & & & & & & & & & & & 7 & 7 & 0.4 \\
\hline Neochrysocharis formosa (Westwood, 1833) & & & & & & & & & & & & 2 & 34 & 36 & 2.2 \\
\hline Neochrysocharis okazakii Kamijo, 1978 & & & & & & & & & & & & 1 & 3 & 4 & 0.2 \\
\hline Pendiobius metallicus (Nee, 1834) & & & & & & & & & & & & & 19 & 19 & 1.2 \\
\hline Pnigalio katonis (Ishii, 1953) & & & & & & & & & & & & & 5 & 5 & 0.3 \\
\hline ハモグリバエ類 & & & & & & & & & & & & & & & \\
\hline Chromatomyiahorticola (Goureau, 1851) & 3 & 3 & 5 & 13 & 10 & 24 & 81 & 36 & 68 & 50 & 258 & 1052 & 602 & 2205 & \\
\hline Liriomyza trifolii (Burgess, 1880) & & & & 1 & & & & & & & & & & 1 & \\
\hline 寄生率 $(\%)^{\mathrm{a})}$ & 0.0 & 0.0 & 0.0 & 6.7 & 9.1 & 4.0 & 9.0 & 10.0 & 13.9 & 10.7 & 29.9 & 11.0 & 69.6 & 42.8 & \\
\hline
\end{tabular}

a) 寄生蜂類の個体数/(ハモグリバエ類の個体数 + 寄生蜂類の個体数 $) \times 100$

科 (Braconidae) の Opius spp. (15.6\%), Di. isaea (11.3\%), ヒメコバチ科 (Eulophidae)の Chrysocharis pentheus (Walker) (9.7\%)，コガネコバチ科 (Pteromalidae) の Sphegigaster hamugurivora Ishii (7.9\%) であった。寄生蜂の寄生率は, 11月と 12 月は $10 \%$ 未満と低く，1月も10\%台だった。し
かし，3 月22日には $29.9 \%$ となり，4月28日には69.6\% まで増加した。

\section{考察}

2016年 1 月から 4 月に三重県津市で行った調査から, 
スナップエンドウ上では，調査期間全体を通してナモグ リバエのマインが観察され（第 1 図), 寄生蜂による寄 生も確認された（第 2 図，第 1 表）。水越・戸川（1999） は，ナモグリバエの発育零点は卵期で $8.6^{\circ} \mathrm{C}$, 幼虫期で $4.9^{\circ} \mathrm{C}$, 蛹期で $4.7^{\circ} \mathrm{C}$ とている。三重県津市で気温が最 も低下する 1 月下旬の日平均気温の平年值は $4.8^{\circ} \mathrm{C}$ であ り，調査を行った2016年は，1月19日から26日に日平均 気温が $0.6^{\circ} \mathrm{C}$ から $4.4^{\circ} \mathrm{C}$ の間で推移したが，それ以外は ほぼ $4.8^{\circ} \mathrm{C}$ を上回っていた（気象庁，2018）。そのため, 当地では，冬期においてもスナップエンドウ上でナモグ リバエ幼虫の発育が進行する条件にあったと推察され る。また，藤原ら（2007）が大阪府枚方市の実エンドウ 栽培戋場で2005年11月から2006年 5 月に行ったナモグリ バエの調査では，気温が最も低い 1 月においても，ナモ グリバエ成虫が黄色粘着トラップに捕獲されたと報告し ている。枚方市の 2006 年 1 月の日平均気温は $1.3^{\circ} \mathrm{C}$ から $9.8^{\circ} \mathrm{C}$ の間で推移し（気象庁，2018）, これは三重県津市 の2016年 1 月の日平均気温の $0.6^{\circ} \mathrm{C}$ から $11.5^{\circ} \mathrm{C}$ の間とほ とんど差がない。したがって，本研究で調査を行った三 重県津市において, 調査期間全体を通してナモグリバエ のマインが観察されたのは， 1, 2 月の低温期も含めて スナップエンドウ上でナモグリバエ幼虫の発育が進行し ていたことに加えて，成虫による産卵活動も継続して行 われていたためと推察される。なお， 2 月 22 日と 3 月 8 日の調査では, 中位葉でのみマインが観察された。これ は，上記の 1 月19日から26日の間の降霜により，一部の 下位葉が枯死したことで，下位葉からマインが採集でき なかったためである。

一方，3月22日以降は上位葉でもマインが観察される ようになり，また，4月 5 日からはマイン数も急増した。 これは, スナップエンドウの株の生長にともなって下位 葉および中位葉ではナモグリバエが産卵可能な葉が減少 したこと，気温の上昇に伴ってナモグリバエ成虫の羽化 個体数が増加し，かつ産卵行動が活発になって多く産卵 されたこと，産卵されたナモグリバエ卵の孵化や幼虫の 発育が速まって発見されるマインが増加したこと，など が原因として考えられる。春どりエンドウに拈りるナモ グリバエの食害が下葉から始まって時間の経過と共に上 方に拡大する状沉は，林・北村（2010）が行った調査で も観察されており，エンドウにおけるナモグリバエの加 害の特徴の一つと考えられる。

次に, 本研究で確認された八モグリバエ類はほぼナモ グリバエ 1 種であった。そのため, マインから羽化した 寄生蜂類は，ナモグリバエの寄生蜂であったと考えられ る。羽化した寄生蜂のうち, 調査期間全体を通して羽化
個体数が全寄生蜂の $10 \%$ 以上になった種は，2016年 1 月から 4 月に三重県津市で行った調査では, H. circulus (40.2 \%), Di. isaea (34.7 \%), Da. nipponica (17.9\%) の 3 種であり (第 1 表), 2016年12月から 2017 年 5 月の 調査では, H. circulus (43.0\%), Di. isaea (26.8\%), Di. minoeus (22.2\%) の 3 種だった（第 2 表）。また, 2016 年12月から2017年 3 月に広島県福山市で行った調査で は, Da. nipponica (75.9\%) が極めて多く採集され，他 にH. circulus (14.8\%) も採集された（第 3 表）。2017年 1 月から 4 月に熊本県合志市で行った調査では, H. circulus (31.1\%), Da. nipponica (17.2\%) Opius spp. (15.6\%), Di. isaea (11.3\%) が多かった（第 4 表）。これら 3 箇所 における調査結果を比較すると, 三重県津市と熊本県合 志市では, H. circulus が最も多く採集されたのに対して, 広島県福山市ではDa. nipponica が最も多くなり, 地域 による優占種の違いが認められた。

寄生蜂種の季節的变化については, 三重県津市と熊本 県合志市では, 概ね 3 月頃まではH. circulus が優占種で あったが，4 月以降にDi. isaea が増加する傾向が認め られた（第 $1,2,4$ 表）。三重県津市で 2 年目に行った 調査や熊本県合志市の調査では, 2017年 1 月下旬に発生 した降霜により 9 月植えのスナップエンドウが枯死した ため, 2 月から 3 月にかけてのデータが欠落している上, それ以降のデータは11〜12月植えのスナップエンドウを 調査して得られたものあり, 㛜密には, 同一のスナップ エンドウ株で得られたデータにはなっていない。しかし, 上述の寄生蜂種の季節的変化は, 同一のスナップエンド ウ株で調査を行った三重県津市の 1 年目の調査でも同様 な傾向が得られている（第 1 表）。杉本（1998）は，寄 生蜂の種構成に影響する大きな要因として温度適応性を 挙げている。そのため, 3 月頃まで H. circulus が優占的 に発生し，4 月以降にDi. isaea が増加する季節的変化は, 両種の温度適応性が影響している可能性が考えらえる。 一方, 広島県福山市では, Di. isaea 自体の羽化個体数が 少なかった。これは, 三重県津市や熊本県合志市では調 査を 4,5 月まで行っていたのに対して, 広島県福山市 では 3 月下旬に調査を終了している。したがって, 同地 においても, Di. isaea は 4 月以降に多く羽化していた可 能性が考えられる。

日本国内に拈けるエンドウでのナモグリバエ寄生蜂類 の発生状況については, いくつかの先行研究が報告され ている。Saito et al.（2008）が静岡県磐田市で行った調 査では，採集された寄生蜂の個体数が全体の $10 \%$ 以上 存在していた種は, Di. isaea（53.2\%；全寄生蜂中の構 成比率，以下同様), Di. minoeus (21.6\%), C. pentheus 
(15.5\%）の 3 種だった。また，島根県松江市では，Di. isaea (23.8\%), Da. nipponica (21.1\%), H. circulus (17.4\%), Dacnusa sasakawai Takada (14.3\%)（林・北村, 2010 ; 2006年と2008年のデータを集計したもの), 山口県山口 市では, C. pentheus (30.6\%), Di. isaea (24.3\%), C. pubicornis (16.3\%),Da.nipponica (13.3\%)（東浦ら, 2011 ; 2002年から2005年のデータを集計したもの), 福岡県糟 屋郡久山町では, C. pentheus (35.2\%),Di. isaea (34.4\%), Da. nipponica (11.5\%), C. pubicornis (10.7\%)（福原・ 高木, 2007 ; 2004年から2006年のデータを集計したも の), 宮崎県宮崎郡清武町（現宮崎市）では, C. pubicornis (27.4\%), Di. isaea (22.3\%), C. pentheus (21.3\%), Da. nipponica (12.5\%)（大野，2004；2003年 2 月26日から 5 月 5 日のデータを集計したもの), 鹿児島県内 9 地域 では, C. pubicornis (31.6\%), C. pentheus (29.6\%), Di. isaea (21.6\%), Da.nipponica (11.7\%)（山口・获崎, 2004), 鹿児島県指宿市では, Di. isaea (49.2\%), Hemiptarsenus varicornis (Girault) (22.5\%), Opius spp. (15.4\%)（柿 元・太田，2017；2016年 1 月12日および 2 月15日のデー タを集計したもの）だった。これらの結果と本研究結果 を比較すると，まず, Di. isaea はすべての地域において 比較的多く採集される寄生蜂であったことから，本種は 全国的に共通な優占種の 1 種と考えられる。一方，本研 究において, 三重県津市と熊本県合志市でナモグリバエ 寄生蜂の優占種とされた H. circulus については, 島根県 松山市以外は多く採集されていない。また，先行研究で 多く採集されているC. pentheus やC. pubicornis の寄生 蜂 2 種は, 本研究では採集個体数が少なかった。ナモグ リバエの主要な寄生蜂種が調査地によって異なる理由と しては, 地域的な種構成の違いが存在すること以外にも, 調査を行った時期や調査戋場における農薬の散布暦の影 響などが考えられる（柿元・太田，2017）。本研究では， 圃場における調査を 12 月から翌年の 5 月の期間に実施し たが, 静岡県磐田市の調査では 1 月から翌年の 5 月の間, 島根県松江市はおもに 4 月から 7 月の間, 山口県山口市 は 3 月から 6 月の間, 福岡県糟屋郡久山町は 1 月から 5 月の間, 宮崎県宮崎郡清武町（現宮崎市）は 2 月から 5 月の間，鹿児島県内 9 地域は 3 月から 5 月の間，鹿児島 県指宿市は 1 月から 2 月の間にそれぞれ実施している。 そのため, 静岡県磐田市の事例以外は, 調査を概ね冬か ら春の時期に実施しており, 調査時期は大きく異なって いなかった。また, 調査期間中に農薬が散布された可能 性があるのは, 調査を農家國場で実施した鹿児島県内 9 地域と指宿市の 2 つの事例のみであった。したがって, 本研究と先行研究において上記のようなナモグリバエ寄
生蜂の優占種が異なっていた理由については, さらに検 討する必要がある。

C. pubicornis については, 日長および気温の増加とと もに，幼虫期に休眠が誘起されることが知られている。 Larios et al.（2007）は，本種の休眠誘起の臨界日長は $25^{\circ} \mathrm{C}$ で12〜14時間の間にあり，また，一度休眠に入っ た個体は， $25^{\circ} \mathrm{C}$ では日長に関わらず休眠覚醒しないと 報告している。本研究では，野外から採集した八モグリ バエ類のマインが付いているスナップエンドウの小葉を $25^{\circ} \mathrm{C} \cdot 14 \mathrm{~L}-10 \mathrm{D}$ (三重県津市の調査), $23^{\circ} \mathrm{C} \cdot 16 \mathrm{~L}-8 \mathrm{D}$ (広 島県福山市の調査）もしくは $25^{\circ} \mathrm{C} ・ 16 \mathrm{~L}-8 \mathrm{D}$ （熊本県合 志市の調査）の条件下で保存した。したがって，これら の高温長日条件により, マインの中に存在していた $C$. pubicornis の休眠が誘起され, 羽化個体数が少なくなっ た可能性も考えられる。

本研究では，スナップエンドウで発生するナモグリバ エには, 気温が低下する冬期においても, 寄生蜂が寄生 していることが明らかになった。しかし，気温が上昇す る 4 月以降はナモグリバエのマイン数が急増し, ナモグ リバエの増加を十分に抑制することはできなかった。そ のため, 土着寄生蜂を活用してスナップエンドウ上のナ モグリバエを抑制するためには，例えば，國場周辺に寄 生蜂が採䬲できる蜜源を供給する植物や寄生蜂の代替寄 主となるハモグリバエ類が多く発生する植物を設置する など, 土着寄生蜂の機能を保護強化する補強技術も必要 と考えられる。

\section{摘要}

春どりのスナップエンドウで発生するナモグリバエ類 と寄生蜂の発生消長と種構成を調べた。ハモグリバエ類 のマインが付いているスナップエンドウの葉を定期的に 採集し, 室内で羽化させて種を明らかにした。三重県津 市では, 調査を行った 1 月から 4 月のすべての期間にお いて，ナモグリバエChromatomyia horticola と寄生蜂に よる寄生が確認された。寄生蜂については, Halticoptera circulus, Diglyphus isaea, Dacnusa nipponica, Diglyphus minoeus などが多く採集された。広島県福山市で行った 同調査では, Da. nipponica が多く採集され, 熊本県合 志市では, H. circulus, Da. nipponica, Opius spp., Di. isaea が多かった。以上の結果から, 三重県津市と熊本 県合志市では, H. circulus がナモグリバエ寄生蜂の優占 種であったのに対して, 広島県福山市ではDa. nipponica が優占種であり，地域間での違いが明らかになった。 


\section{引用文献}

林 由起・北村憲二（2010）ホシザキグリーン財団研究報告 $13: 1-13$.

東浦祥光・岩本哲弥・和泉勝憲（2011）山口農技センター研報 $2: 55-66$.

福原史樹・高木正見（2007）九大農学芸誌 62(1) : 1-6.

藤原亮介・田中 寛・福田 渉・徳丸 晋・柴尾 学・瓜生恵 理子（2007）関西病虫研報 $49: 97-99$ 。

柿元一樹・太田 泉（2017）九病虫研会報 $63: 46-54$.

気象庁（2018） URL : http://www.jma.go.jp/jma/index.html（2018 年 8 月アクセス)

小西和彦（2007） Jpn. J. Ent. (N.S.) 10(3) : 53-61.

小西和彦（2010） IV. 参考資料 資料 2 ：八モグリバエ類寄生

蜂の検索表. 環境 Eco 選書 3 絵かき虫の生物学（広渡俊 哉編)。北隆館, 東京, pp. 218-236.
Larios, G. L. B., K. Ohno and F. Fukuhara (2007) Appl. Entomol. Zool. 42: 189-197.

水越 亨・戸川 浩（1999）北日本病虫研報 $50: 169-172$.

大野和朗（2004）農生態系の土着天敵を活用した八モグリバエ 類の生物的防除. 平成 14 年度 15年度科学研究費補助金 (基 板研究 (c) (2) ) 研究成果報告書. $52 \mathrm{pp}$.

西東 力 (2005) 植物防疫病害虫情報 $76: 3-4$.

Saito, T., M. Doi, H. Katayama, S. Kaneko, Y. Tagami and K. Sugiyama (2008) Appl. Entomol. Zool. 43: 617-624.

新藤潤一・石谷正博 - 北野のぞみ（2008）北日本病虫研報 59 : 174-178.

杉本 毅（1998）植物防疫 $52: 341-345$.

Takada, H. and K. Kamijo (1979) Kontyû, Tokyo, 47 (1): 18-37.

山口卓宏・嶽崎 研 (2002) 今月の農業 48(12) : 36-41. 